\title{
The Conceptual Framework of the Effect of Location on Performance of Small Firms
}

\author{
Mohd Sobri Minai (PhD) \\ College of Business, Universiti Utara Malaysia, Malaysia \\ Esuh Ossai-Igwe Lucky \\ College of Business, Universiti Utara Malaysia, Malaysia \\ Tel: 60-1-461-7732 E-mail: igwedegreat@yahoo.com
}

Received: April 25, 2011

Accepted: June 27, 2011 Published: December 1, 2011

doi:10.5539/ass.v7n12p110

URL: http://dx.doi.org/10.5539/ass.v7n12p110

\begin{abstract}
There are abundant studies examining the performance of small firms with their studies frameworks. Most of the studies focus on the common attributes and categories that neglect the aspect of location. However, the inconsistent results on the relationship between entrepreneurial factors and firm performance have led the authors to propose a contingency model in which the effects of individual determinants, external factors and firm characteristics on firm performance are moderated by location. The paper argues the significance importance of location factor in the development of entrepreneurship and small business in Nigeria and thus suggests that location factor should be given an urgent consideration as a vital factor that would positively affect small business performance.
\end{abstract}

Keywords: Entrepreneurship determinants, Location, Entrepreneurship development

\section{Introduction}

The constant examination on entrepreneurship development is almost becoming a routing exercise by many researchers in various countries (Greening, Barringer and Macy, 1996, Rebecca and Benjamin, 2009 and Rajesh, 2006). For instance, in India, Rajesh (2006) reported that India government is mobilizing a large population of capable of entrepreneurial activities. In Nigerian, Arowomole, (2000) asserted that every successive government continues to emphasis on entrepreneurship development. This is probably to find a better way of nurturing the entrepreneurship development by looking for those entrepreneurial factors such as location that could effectively and positively affect the entrepreneurial development as well as that of the firm performance.

With reference to above, many past studies have documented the significant impact of entrepreneurial factors such as individual determinants, external factors and firm characteristics on entrepreneurial performance. For instance, Mohd (2005), Blackman (2003), Ogundele (2007), Colin et al. (2005) and Lawal (2005) argued that individual determinant which is also called entrepreneurial characteristics significantly and positively affect both entrepreneurial development and entrepreneurial performance. Similarly, Van De Ven (1993), Mohd (2005), Arowomole (2000), Kuratko et al. (2004) and Kader, Mohamad and Ibrahim (2009) have asserted that external factors predict and significantly affect entrepreneurial performance as well as entrepreneurship develoment of any country. With respect to this, Van De Van (1993) has further argued that any study within the field of entrepreneurship development without the consideration of external factors which he nicknamed external environement should be considered incomplete and invalid. Accordingly, Johan et al. (2005), Mohd (2005), Lim (2006) and Dean et al. (2000) argued that firm characteristcis such as firm size, nature of firm etc affect the performance of the firm.

From the above, there is no doubt that past studies have really given attention to the impact of individual determinants, external factors and firm characteristics on firm performance (Rebecca and Benjamin, 2009, Willian, 2009, Zhang et al. 2008, Okpara et al. 2007 and Ogundele, 2007). Despite the attention extended to these factors, Man, Lau and Chan, (2002) have argued that all these factors still deserve further attention in the study of entrepreneurship and small business. However, while different factors such as individual determinants, 
external factors and firm characteristics have been found to influence entrepreneurial performance to different extents, the results are often inconsistent (Man et al. 2002, Yanfeng and Si, 2008, 2008, Kisfalvi, 2002, Dean et al. 2000, Pelham, 1999; Chandler and Hanks, 1994, Cooper, 1993). In order to tackle this problem, past studies have suggested contingency relationships on different conditions and interactions (Fanga, Evans and Zou, 2005, Man et al. 2002), in line with this, this study therefore, proposes a contingency model in which the effects of individual determinants, external factors and firm characteristics on firm performance will be moderated by location. Thus, this paper argues on the crucial importance of location factor in the entrepreneurial and business development. Therefore, the need to investigate the moderating role of location on the relationship between individual determinants, external factors and firm characteristics with firm performance becomes imperative in this regard. It is hoped that the study shall provide both theoretical and practical implications.

\section{Literature Review and Hypotheses Development}

\subsection{Individual determinant}

The individual determinant is highly rooted in the psychology theory of entrepreneurship. Theorists of this concept have greatly stressed the need for entrepreneur to possess certain entrepreneurial characteristics and apart from those individual characteristics needed to develop entrepreneurship as such it is imperative to examine the relationship between entrepreneurship development and individual characteristics. The individual characteristic could also be referred to as entrepreneurial characteristics or qualities.

Within the context of this discussion, the individual determinant is being discussed under the perspective of individual characteristics. First, it is important to note that entrepreneurial firm are created by entrepreneurs who posses certain characteristics or personalities that enables them to manage the firm and achieve success. These characteristics are therefore needed in entrepreneurship development. Thus, they formed the crucial point of this discussion. It is crystal clear that studies on the entrepreneur' characteristics are quite abundant, right from the time of Cantillon in 1755, Schumpeters in 1934, Say in 1821, McClelland in 1961 and a host of others. For instance, Olanrewaju (2009) found that the entrepreneurial characteristics are strongly impacting on the entrepreneurial performance of small-scale business. William (2009) in assessing Zimbabwe's entrepreneurship noted that if all the requisite entrepreneurial and managerial skill which forms the products of entrepreneurial characteristics is acquired either by the entrepreneurs themselves or by the management for SMEs, they could translate these skills into entrepreneurial performance. Therefore, there is positive relationship between entrepreneurial characteristics and entrepreneurial development.

In line with this, Mohd (2005) noted that entrepreneurial characteristics can influence the type of firm that will be created as well as how it will be managed. Thus, it is important to understand the entrepreneurial characteristics of the entrepreneurs. Several studies have listed the personality characteristics needed to develop entrepreneurship, for example, need for achievement, motivation, knowledge, skills, locus of control etc.

Blackman (2003) asserted that individual's characteristics are both attributed to the achievement which also has direct effect to the entrepreneurial firm performance. Colin, Gerard, David and Robert (2005) argued that there is a little point, therefore, in trying to match yourself up to this or that personality type. However, there are some fairly broad characteristics that are generally accepted as being essential if one is going to ensure the success of the entrepreneurial firm in terms of its performance. Supporting these arguments, Lawal (2005) and Ogundele (2007) in their studies of indigenous entrepreneurial development found that entrepreneurial characteristics which they called personal and psychological factor affect entrepreneurial performance. Furthermore, being fully aware of the complex nature of individual determinants variable in the academic field of entrepreneurship, therefore, this study considers and focuses on five crucial variables of individual determinants-mental capacity, motivation and needs, gender, biological make up and attitude, and they are called the individual determinants.

\subsection{External determinant}

External determinant has been described in various ways. For instance, it has been seen as mean situations in the environment while other studies view it as conditions found in the entrepreneurial environment. Mohd (2005) has also described it as factors that are capable of dictating the failure and success of the entrepreneurial firms. The role of external environment has been widely recognized in determining and dictating the performance and the continue existence of the entrepreneurial firms most especially in the critical time. Therefore, there is need to examined the entrepreneurship development with respect to eternal environment.

Several studies have really examined the impact of eternal environment on the entrepreneurial performance. Hence, some body of knowledge exists in this regard. For instance, Mohd (2005) have shown that external factors have vital role to play in the determination of the failure or success of the entrepreneurial firms. Also 
study by Arowomole (2000) noted that eternal factors can assign boundaries to entrepreneurial firm and entrepreneurs' decisions and on the other hand provide opportunities from the environment. Similarly, Van De Ven (1993) has argued in his work that any study in the field of entrepreneurship which does not regard other variables such as environment should be regarded as insufficient and incomplete. He asserted that research in entrepreneurship should try to look at or view entrepreneurship in a social system perspective which on the other hand gives attention to external environmental conditions and thus, should be considered more appropriate in the explanation of entrepreneurial process. Supporting this, Arowomole (2000) noted that the various factors, forces and actors that make up the external determinant could be the problems or opportunities to the entrepreneurs and therefore can effectively determine or influence the entrepreneurial competence and performance. Kuratko and Hodgetts (2004) also suggested that external factors could directly or indirectly affect or influence the entrepreneurial decisions thereby also affecting the performance. This study considered and focused on economic and environmental dimension of external factors based on the work of Kader et al. (2009).

\subsection{Firm characteristics}

Entrepreneurial firms are being managed by the entrepreneurs. Some of these firms are micro while others are small in sizes. The nature and the size of the firm including the firm knowledge are very crucial factors that will affect firm performance. These factors form the firm's characteristics in this study. Thus, it is very important to examine the significant relationship between firm characteristics and firm performance.

Previous studies have documented the relationship between firm characteristic and entrepreneurship. For instance, Mohd (2005) asserted that firm characteristics seem to play a vital role in determining the performance of the firm and can further determine how well the entrepreneurship have been developed in the country. Wiklunda and Shepherd (2005) using the logic of the configuration approach which they rest on the premise that firms that are able to align certain firm attributes with the characteristics of the environment outperform other firms. Hence, those firms that failed to achieve such alignment will eventually be competed out. They further argued that a limited number of configurations of firm and environmental attributes can be used to describe the large proportion of high-performing firms.

Furthermore, empirical studies have also documented that positive relationship exists between firm characteristics and entrepreneurial development. Dean, Bülent and Christopher (2000) reported that size affects a firm's marketing capabilities, attitudes, needs, practices etc which are important determinants to firms' performance and success. In line with the above, Cubbin and Leech (1986) and Dobson and Gerrard (1989) found a positive relation between firm size and performance which they measured by growth and profitability. Also, Power and Reid (2003) in their study found a trade-off between firm size and performance.

However, Dean et al. (2000) reported that the connection between firm size which is contained in the firm's characteristics and entrepreneurial performance is a controversial issue in the field of research. They asserted that other studies that have investigated the issue of size to identify gap between group differences produced mixed results. Another study also reported similar thing, summarizing the major findings of five studies based on an extensive review of existing literatures with all the authors concluding that the empirical findings on the relationship between firm size and export intensity (entrepreneurial performance) are all producing mixed findings.

\subsection{Moderating effect of location}

Arguably, the most important factor of entrepreneurship and small business development is the strategic location of the business which could include the nearness to raw material, accessibility to business premises, good road network, busyness of the area of the business etc. Ilian and Yasuo (2005) defined location as the choice mode of entering business and viewed location in terms of type which could be local or international location. Also, Kala et al., (2010) defined location as choice of where a business is to be located, be it small, medium and large cities or urban or rural locations. This definition is in line with Esteban, Yancy and Christian (2010) who referred to location as the choice of locating your business either in the rural or urban centre and they also linked location with the type of product or service the firm tend to offer. Orloff (2002) defined location to include the followings: economic situation, density of entrepreneur's per capita, composition of local communities etc to location. Therefore, location could be defined as nearness and accessibility of the firm to raw materials, infrastructures, how busy the location is? How accessible the location is to the customers etc?

Location is an indispensible factor that shapes and determines the success or failure of entrepreneurial development and business activities. It determines the effectiveness of the entrepreneurial and business activities. Previous studies have revealed that firm performance is direct influenced by individual determinants, external factors and firm characteristics (Blackman (2003), Ogundele (2007), Colin et al. (2005), Lawal (2005), Van De 
Ven (1993), kedah et al. (2009), Lim (2006) and Dean et al. (2000). However, there have been inconsistent findings in the respective studies, giving room for the introduction of a moderating variable. The inconsistent findings also indicate that some important variables such as location have not been considered in the previous studies. On this note, it is necessary to examine the role of location as a moderator that affect the relationship between individual determinant, external factor and firm characteristics with firm performance. The essence of this is to further strengthen the relationship between individual determinant, external factor and firm characteristics with firm performance. In this case, it is expected that location would significantly and positively affect the relationship between the individual determinant, external factor and firm characteristics, and firm performance. With the presence of location, it is assumed that the relationship between individual determinant, external factor and firm characteristics, and firm performance would become stronger and effective. Hence, location plays a crucial role in the effectiveness of individual determinant, external factor and firm characteristics on firm performance. Therefore, it is argued here that it is not only important for firms, policy makers and entrepreneurs or business owners to consider individual determinants, external factors and firm characteristics but that the effectiveness of these factors on the firm performance may depend on the strategic location of the firms which then strengthen the effectiveness.

Kala et al. (2010) has reported that the strategic location of the domestic firms has assisted them in achieve a positive performance. It can be argued here that location has provided domestic firms with strong force to prosper and succeed in their business. They equally noted that location has helped the firms in the area of sustainability and also imply performance. Accordingly, Orloff (2002) has provided evidence on the effect of location on emergence of entrepreneurs and consequently their performance. His study reported that location plays vital role in entrepreneurship development.

From the on going, one could see that the location is vital factor of entrepreneurship development that when aligned with other entrepreneurial factor like individual determinant, external factor and firm characteristics could highly affect the entrepreneurship development and firm performance.

\subsection{Small firm performance}

Trkman, (2009) noted that performance measure is indispensable for entrepreneurial and small firms because it helps them to ascertain the success or failure of the firm and also acts as an indicator to achieve sustainable improvement in entrepreneurial and business activities. Accordingly, Murphy, Trailer and Hill (1996) argued that "accurate performance measurement is critical to understanding new venture and small business success and failure". However, generally, the concept of performance is very hard to operationalized in the field of research most especially in the field of entrepreneurship and small business. Moreover, one cannot rule out performance when talking about small firms since the achievement of the small firms is being measured by their performance.

Furthermore, small firm performance measurement has been viewed in two major dimensions; the financial and non-financial dimensions. Financial measure of performance includes profit and growth. It seems that researchers have different opinion on which of these small firm measurement best measure performance. However, according to (Murphy et al, 1996), it seems that more authors have the opinion that financial measure of small firm performance is the best indicator of performance. This may be due to the fact that financial measure such as profitability is the focus of the overall objective of most firms in which small firms are not left out. Indeed, financial measure is the primary measure of a firm success and performance (Murphy et. al 1996). They argued, within the context of small firms and entrepreneurship development, the financial measure of small firms seems to be common and widely used. In this case, they further suggested that in the academic field and as well as entrepreneurial field financial indicators have gained the upper hand when discussing on performance. This is due to; it is easy to use in ranking and judging how a firm performs in its business operations or activities.

On the other hand, the non-financial measure of performance which is equally referred to as operational measure is becoming popular to measure the small firm's performance (Murphy et al., 1996, Panigyrakis and Theodoridis, 2007). For instance, Ittner and Larcker (2003) argued that non-financial performance measure helps managers and owners to ascertain the progress of the business, although, it is very subjective unlike the financial measure. Campbell, (2007) asserted that non-financial measure seems to compliment the financial measure in determining the firm's performance. However, in line with the above arguments and considering the uniqueness of the small firms, and coupled with the uniqueness of 1 entrepreneurs in organizing and managing their firms, using a single dimension of small firm performance shall not give a better result. Hence, this study adopts both financial and non-financial objective measurement of profitability and growth of small firm performance. Muhammad (2009) concurred that these two indicators of financial and non-financial measures seem to be important to entrepreneurial firms as well as small firms. The research framework is presented at the end of the article. 
Orloff (2002) has asserted that the location factor plays a very vital role in the development of entrepreneurship. This is in line with the role location played in the emergence of entrepreneurs in Canada. Accordingly, Yanfeng and Chunlin (2008) found out the significant role of location in the growth of Chinese entrepreneurial enterprises. Another study by Ilian and Yasuo (2005) found that location plays a crucial determinant role in the expansion of firms and industries. Based on the above argument, it is evidenced that location factor plays important role in the entrepreneurship development. Thus, this study commences to examine the effect of location as the moderator to the relationship between individual determinant, external factor and firm characteristics with firm performance. It is visualized that the location factor strengthens the relationship between individual determinant, external factor and firm characteristics with firm performance.

In the study, the following hypotheses are being advanced:

Hypothesis 1: there is no significant relationship between individual determinant and firm performance

Hypothesis 2: there is no significant relationship between external factor and firm performance

Hypothesis 3: there is no significant relationship between firm characteristics and firm performance

Hypothesis 4: location does not moderate the relationship between individual determinant and firm performance

Hypothesis 5: location does not moderate the relationship between external factor and firm performance

Hypothesis 6: location does not moderate the relationship between firm characteristics and firm performance

\section{Methodology}

\subsection{Sampling}

The study utilizes the cross-sectional study method of questionnaire survey approach with a simple random sampling technique where the entrepreneurs and owner-managers of small firms in Lagos state are selected as the targeted population. The sample respondents in this study include both the entrepreneurs and owner-managers who have registered with the Lagos state government. In this case, the respondents are identified through the Lagos state business directory, obtained through the Lagos stage government website. The study through a systematic random sampling will identify 300 entrepreneurs and owner-managers to be included in this study.

\subsection{Data collection method}

A pilot study was conducted on thirty (30) owner-managers within the locality in order to assess the reliability of the existing scale. Accordingly, the scale was modified so as to suit the context of this present study. Data collection of this study is based on quantitative method of survey questionnaire which is self-administered on both the owner-managers and the entrepreneurs of small firms in the three major areas as categorized by the Lagos state government. At the early stage, the respondents were first contacted via E-mail and mobile phone in order to inform them about the survey.

\subsection{Measurement of variables}

The study will use the primary data collection questionnaire survey technique to achieve its objective. the questionnaire consists of five sections; the profile of the respondents and their business, individual determinant, external factor, firm characteristics, location and firm performance. All variables in this study are measured using a five-point Likert scale ranging from $1=$ strongly disagree to $5=$ strongly agree and this shall assist in measuring the extent to which respondents agree or disagree to each of the statement or questionnaire. Individual Determinant is measured using 37 items of five dimensions, External Determinant is equally be measured with eight items that are adopted and modified from previous studies. The study also measures firm characteristics with fifteen items of three dimensions. Items are adopted from previous studies, however, are modified for the purpose of this study. Location factor is also been measured using eight items that are adopted from the works of Yanfeng and Chunlin (2008) and, Ilian and Yasuo (2005). Finally, firm performance is measured with ten items adopted from the various works of Francisco and Yi-Wen (2006) and Ogundele (2000), Shradha et al. (2005) and Murphy et al. (1996).

\subsection{Data analysis techniques}

The data that is collected from the main survey is subjected to data cleansing and data cleaning in order to identify missing value, sample characteristics and meet the assumptions of normality. After this, the descriptive analysis is used to summarize the respondents' characteristics and their businesses. Factor analysis is employed in this regard to help in identifying the actual number of factors that actually measures each constructs to be used in this study as perceived by the respondents. In this case, the component factor analysis with varimax rotation is 
therefore conducted on all the variables to extract factors from the scales of each construct. The researchers ensure that all items have a well loading factor above recommended loading factor. In this study, all items with below 0.50 are not retained. In the reliability test, variables with less than Cronbach' Alpha coefficient of 0.50 are not included in the analysis. Equally, the variables are subjected to validity test. The validity test on instrument in this study is measured through Bartlett's Test of Sphericity (Muhammad, 2009). All variables with KMO above 0.6 as recommended by Chakraborty (2010), Trent, Justen, Anastasios (2009), Nuradli, Hanifah, Shahida, Hairunnizam (2008) and Dahal (2004) are accepted.

\section{Limitation and Recommendation for Future Study}

Obviously, there is no research without its limitations. This study only covers both manufacturing and service industries in Lagos, Nigeria. Therefore, this could limit the generalibility of the findings to other sectors such as the trading and distribution sectors which seem to also play a vital role. Sekaran, Robert and Brain (2001) argued that when the research findings are more generalizabled then the greater the usefulness of the findings and as well as its value. Again, the research method that is adopted in this study may have some limitations on the findings applicability. Based on these arguments, this study therefore recommends that future research should focus and cover the other sectors such as trading and distributive sectors. In addition, the other research methodologies other than the one adopted in this study should be considered. This shall help to establish the better generalisibility of the research findings obtained from the study.

\subsection{Conclusion}

The findings of the moderating effect of location on the relationship between individual determinants, external factors and firm characteristics with the firm performance will no doubt provide interesting contributions. First, to the study, the contribution is very visible in the body of literature within the academic field of entrepreneurship development as this study is the first study to investigate the effect of location as the moderating variable in the relationship between entrepreneurial factors (the individual determinants, external factors and firm characteristics) and firm performance. Accordingly, it provides unique and important information about the vital role of location factor for most SMES firms, policy makers and entrepreneurs in making decisions about how they can strategically locate their firms for effective and better firm performance.

It is concluded here that the location factor is an important factor in the entrepreneurship development. This factor must be adequately considered as it has been found to contribute significantly to the development of entrepreneurship and the success of the entrepreneurs. Countries such as U.S.A, Canada and UK have recognized the role of location factor by building industrial packs and centers and they have continuously emphasized on them. This has no doubt helped them to enhance and improve their entrepreneurship development. Furthermore, the location factor which has been given little attention by some must be considered as essential and vital in developing the entrepreneurship. The location factors understudied include; nearness to raw material, access to business and access to technologies. From the evidence, it is concluded that if location factor is being given urgent consideration in Nigeria, this factor is capable of changing the entrepreneurial scenario and thereby serving as a driver and motivating force in achieving entrepreneurial success. It is suggested here that, the strategic location of any firm is the beginning of the firm's success.

\section{References}

Arowomole, K. A. (2000). Modern Business Management(Theory and Practice), (1st Edition). Sango-Ota, Ogun State: Ade-Oluyinka Commercial Press (Chapter 132).

Blackman, A. J. (2004). Entrepreneurs: Interralationship between their Characteristics, Nalues, Expectations Management Practices and SME Performance.

Chakraborty, S. (2010). A Study of Select Discount Store Retail in Hyderabad for the Purpose of Identifying Factors in Regards to Shopping Motives, Store Attributes, Shopping Outcomes and Perceived Shopping Cost. Inte rnational Journa l of Global Business, 3(1), 1-19.

Chandler, G., \& Hanks, S. (1994). Founder Competence, the Environment, and Venture Performance. Entrepreneurship Theory Pract, 18 (3), 77-89.

Colin, B., Gerard, B., David, M., \& Robert, B. (2005). Enterprises Development: The Challenges of Starting, Growing and selling Businesses. London: Thomson Learning Publisher.

Cooper, A. C. (1993). Challenges in Predicting New Firm Performance. Journal Business Venturing, 8(3), 241-253. http://dx.doi.org/10.1016/0883-9026(93)90030-9 
Cubbin, J., and Leech, D. (1986). Growth versus Profit Maximisation: a Simultaneous Equations Approach to Testing the Marris Model, Managerial and Decision Economics, 7, 123-31.

Dahal, H. (2004). Factor Analysis for Soil Test Data: A Methodological Approach in Environment Friendly Soil Fertility Management. Ministry of Agriculture and Cooperatives .

Dean, D. L., \& Bülent Mengüç, C. P. (2000). Revisiting firm characteristics, strategy, and export performance relationship: a survey of the literature and an investigation of new zealand small manufacturing firms. Industrial Marketing Management, 29, 461-477. http://dx.doi.org/10.1016/S0019-8501(99)00085-1

Dobson, S. and Gerrard B. (1989). Growth and Profitability in the Leeds Engineering Sector. Scottish Journal of Political Economy, 36 (4), 334-52.

Esteban, L., Yancy, V., \& Christian, S. (2010). Location Decisions of Knowledge-Based Entrepreneurs: Why Some Catalan Kisas Choose to be Rural? Technovation.

Francisco, L., \& Yi-Wen, C. (2006). Testing The Entrepreneurial Intention Model On A Two-Country Sample. Departament d'Economia de l'Empresa.

Greening, D. W., Barringer, B. R., \& Macy, G. (1996). A Qualitative Study Of Managerial Challenges Facing Small Business Geographic Expansion. Journal of Business Venturing, 11, 233-256. http://dx.doi.org/10.1016/0883-9026(95)00108-5

Henri, J.-F. (2006). Organizational Culture and Performance Measurement Systems. Accounting, Organizations and Society, 31, 77-103. http://dx.doi.org/10.1016/j.aos.2004.10.003

Ilian, P. S., \& Yasuo, H. (2005). Influence Of Location Factors On Establishment and Ownership of Foreign Investments: The Case Of The Japanese Manufacturing Firms in Europe. International Business Review, 14, 577-598. http://dx.doi.org/10.1016/j.ibusrev.2005.06.001

Kader, R. A., Mohamad, M. R., \& Ibrahim, A. A. (2009). Success Factors for Small Rural Entrepreneurs under the One-District-One-Industry Programme in Malaysia. Contemporary Management Research, Vol. 5, No. 2, 147-162.

Kala, S. S., \& Guanghua, W. (2010). Firm location choice in cities: Evidence from China, India, and Brazil. China Economic Review, 21, 113-122. http://dx.doi.org/10.1016/j.chieco.2009.11.003

Kisfalvi, V. (2002). The Entrepreneur's Character, Life Issues, and Strategy Making a Field Study. Journal of Business Venturing, 17, 489-518. http://dx.doi.org/10.1016/S0883-9026(01)00075-1

Kuratko, D. K., \& Hodgetts, R. M. (2004). Entrepreneurship: theory, process \& practice, (6th Edition). United States of American: Thomson South-Western.(Chapter 201).

Lawal, A. A. (2005). Management Practices and Organisational Effectiveness in Nigeria Small And Medium Enterprises(SMEs). Akoka, Lagos: University of Lagos.

Michael, C. A., Jackson, D. N., \& Wroblewski, V. R. (2000). The Impact of Faking on Employment Tests: Does Forced Choice Offer a Solution? Human Performance, 13(4), 371-388. http://dx.doi.org/10.1207/S15327043HUP1304_3

Mohd, K. H. (2005). Small and medium-sized enterprises in malaysia-role in isuues. Sintok: UUM Press.

Muhammad, M. A. (2009). the combine effect of market orietation and owner/manager's innovation and business performance of small and medium sized manufacturing firms in pakistan. Sintok, Kedah, Malaysia: $\mathrm{PhD}$ Thesis, UUM.

Murphy, G. B., Trailer, J. W., \& Hill, R. C. (1996). Measuring Research Performance in Entrepreneurship. Journal of Business Research, 36, 15-23. http://dx.doi.org/10.1016/0148-2963(95)00159-X

Ogundele, O. J. (2007). Introduction to entrepreneurship development, corporate government and small business management. (1st Edition). Lagos: Molofin Nominees.(chapter 113).

Okpara, J. O., \& Wynn, P. (2007). Determinants of Small Business Growth Constraints in a Sub-Saharan African Economy. SAM Advanced Management Journal.

Olanrewaju, O. (2009). Entrepreneurship and Performance of Small-Scale Enterprises in Nigeria. Nigerian Economic Society Journal, 47(2).

Orloff, A. (2002). Social Venture Partners Calgary: Emergence and Early Stages. Canadian Centre for Social Entrepreneurship. 
Pavlos, D., Spyros, L., \& Sara, C. (2004). The Relationship Between Entrepreneurship And International Performance: The Importance Of Domestic Environment. International Business Review, 13, 19-41. http://dx.doi.org/10.1016/j.ibusrev.2003.08.001

Pelham, A. M. (1999). Influence of Environment, Strategy, and Market Orientation on Performance in Small Manufacturing Firms. Journal of Business Research, 45, 33-46. http://dx.doi.org/10.1016/S0148-2963(98)00026-5

Power, B. and Reid, G.C. (2003). Performance, Firm Size and the Heterogeneity of Competitive Strategy for Long-lived Small Firms: A Simultaneous Equations Analysis. Working paper.

Rajesh. (2006, February 28). Entrepreneurship Development: Concept and Context. Indian, Indian, Indian. Do Bata: A corporate Goreto Web site. [Online] Available: http://dobato.blogspot.com/2006/02/entrepreneurship-development-concept.html (January 8, 2010)

Rebecca, E. O. (2009). Entrepreneurial Competencies: The Missing Links to Successful Entrepreneurship in Nigeria. International Business Research, 2(2), 62-71.

Robert, J. T., \& Sammi, K. L. (2007). Measuring Chinese Entrepreneurial Motivation Personality and Environmental Influences. International Journal of Entrepreneurial Behaviour \& Research, 13(4), $200-221$. http://dx.doi.org/10.1108/13552550710759997

Sekaran, U., Robert, Y. C., \& Brain, L. D. (2001). Applied Business Research. (1st edition). Australia: John Wiley \& Sons Australian Ltd.(chapter 13).

Shradha, S., Mukherjee, S., \& Sharan, R. (2005). Structural Interventions For Favourable Sociocultural Influences On India Entrepreneurs. Indian.

Trent, D. B.; Justen, P. O’Connor \& Anastasios, N. B. (2008). Instrumentation and Motivations for Organised Cycling: the Development of the Cyclist Motivation Instrument (CMI). Journal of Sports Science and Medicine, 8, 211-218.

Van De Van, A. (1993). The Development of Infrastructure for Entrepreneurship: Key Dimensions and Research Implications. Journal of Business venturing, 8, 211-230.

Ventkataraman, N., \& Ramanujam, V. (1986). Measurement of Business Performance in Strategy Research: A Comparison of approaches. Academy of Management Review, 801-814.

Wiklunda, J., \& Shepherd, D. (2005). Entrepreneurial Orientation and Small Business Performance: A Configurational Approach. Journal of Business Venturing, 20, 71-91. http://dx.doi.org/10.1016/j.jbusvent.2004.01.001

William, M. (2009, April Thursday). Managerial Skills for Small to Medium Enterprises and the Informal Sector to Enhance Development and Business Growth. Zimbabuwe, Zimbabuwe.

Yanfeng, Z., \& Si, C. (2008). The Impacts Of External Factors on the Growth Of Chinese Entrepreneurial Enterprises an Empirical Study. Journal of Small Business and Enterprises Development, 15 (4), $689-703$. http://dx.doi.org/10.1108/14626000810917807

Yong-Hui, L., Jing-Wen, H., \& Ming-Tien, T. (2009). Entrepreneurial Orientation and Firm Performance: The Role of Knowledge Creation Process. Industrial Marketing Management, 38, $440-449$. http://dx.doi.org/10.1016/j.indmarman.2008.02.004 


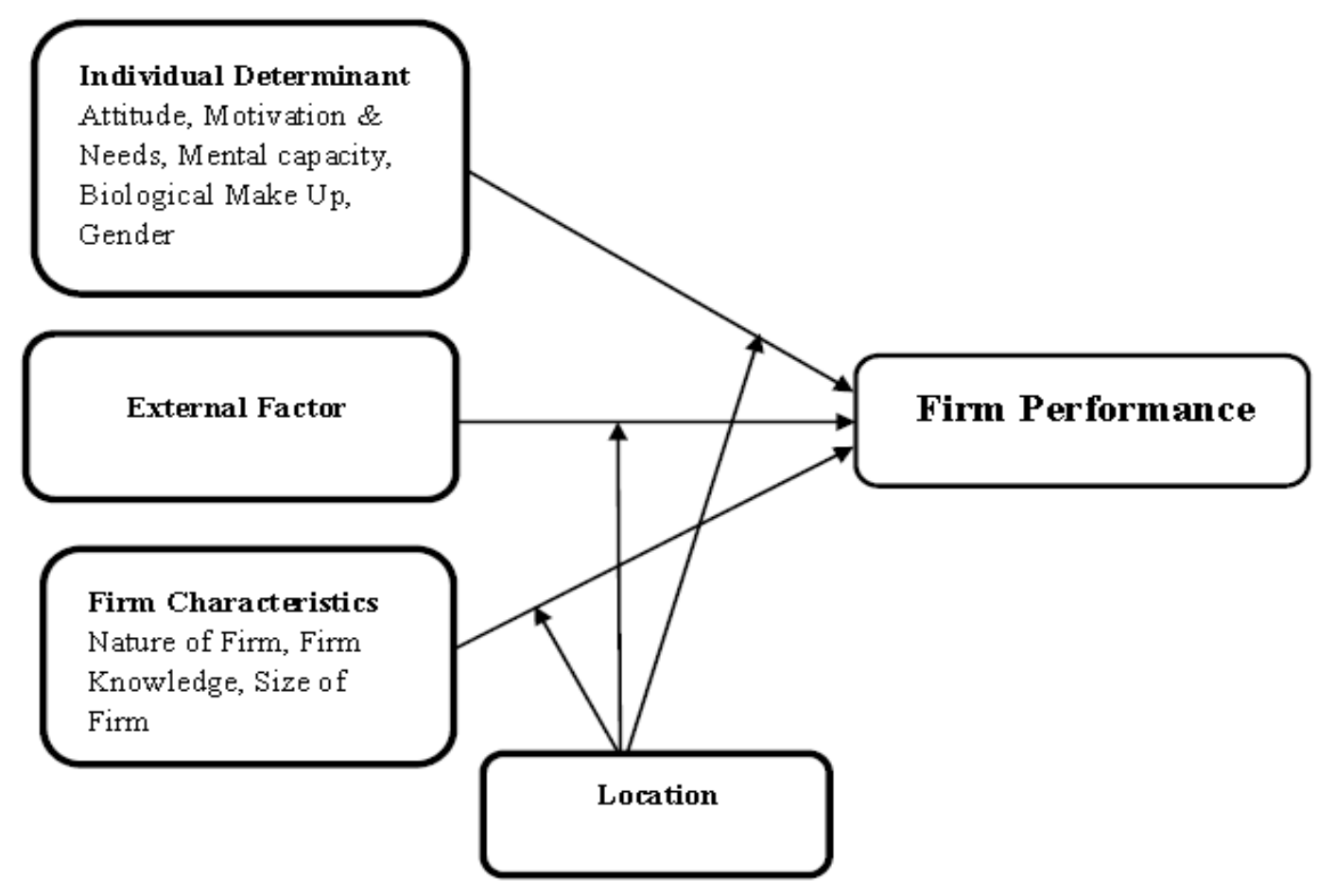

Figure 1. Proposed research framework 